\title{
Confiança e reciprocidade entre policiais e cidadãos: a polícia democrática nas interações
}

\author{
Rodrigo Figueiredo Suassuna \\ Orientador: Prof. Dr. Maria Stela Grossi Porto \\ Curso: Doutorado em Sociologia \\ Data da Defesa: 21.05.2013
}

ste trabalho tem por objeto principal as interações entre policiais e cida-
dãos em um contexto urbano moderno, enfatizando o estabelecimento ou
ruptura da confiança na relação entre prestadores e usuários dos serviços de polícia. As informações que fundamentam este estudo foram produzidas por meio de pesquisas envolvendo as experiências de atores sociais de dois tipos: (a) a população civil que utiliza os serviços de polícia na Grande Brasília; (b) os policiais militares e civis que atuam nesta cidade. O método utilizado foi a etnografia, centrada na observação de interações entre policiais e cidadãos em delegacias de polícia, conselhos comunitários de segurança e vias públicas policiadas. Além disso, foram coletadas narrativas proferidas por cidadãos que se percebem como vítimas de violência policial e foram utilizadas informações provenientes de surveys realizados com policiais militares e civis do Distrito Federal. Utiliza-se a noção de confiança proveniente da etnometodologia, que define o fenômeno como a interação orientada por determinadas expectativas de reciprocidade. A etnometodologia, por meio de procedimentos demonstrativos, propõe que, quando as expectativas de reciprocidade são frustradas, a interação entra em colapso, pois os participantes não conseguem dar sentido ao contato com os outros. Considerando as interações entre policiais e cidadãos, as rupturas na confiança foram agrupadas como (a) questões de compromisso, relacionados ao desvio de atenção empreendido por policiais ou usuários, em detrimento da atenção recíproca pressuposta nas expectativas de confiança; e (b) questões de competência, em que as interações conformavam cerimônias de degradação do status de indivíduos presentes ou ausentes nos encontros. A atenção desviada dos encontros entre policiais e cidadãos voltava-se para normas procedimentais das organizações pesquisadas ou para aspectos de suspeição vinculados ao local de atuação do policial. Por outro lado, muitos policiais lograram "administrar" as condições de atenção dos encontros, promovendo a confiança. Já as cerimônias de degradação dirigiam-se especialmente àqueles destituídos do status de vítimas criminais, aos que tinham menos de dezoito anos e, em certos casos, o próprio policial empreendia uma autodegradação, apresentando-se como impotente. Este trabalho pautou-se também pela verificação dos efeitos das 
instituições sobre a confiança, entendendo-se instituições como rotinas historicamente consolidadas que se configuram como elementos externos aos encontros. Na medida em que as instituições produzem assimetria, alienação da interação e homogeneização das apresentações dos participantes, a confiança entre policiais e cidadãos viu-se desfavorecida por instituições como: (a) procedimentos burocráticos das organizações; (b) tradições profissionais policiais; (c) o direito à segurança; e (d) prerrogativas de autoridade policial. Por outro lado, verificou-se que certas instituições empoderam atores cujo status foi previamente degradado, favorecendo a confiança na competência. Já a análise das narrativas de cidadãos que se veem como vítimas de violência policial aferiu os conteúdos das expectativas de reciprocidade dos cidadãos para com os policiais, conteúdos que foram evidenciados com a ruptura na confiança na relação policial-cidadão. Verificou-se, ainda, que muitas dessas expectativas deixaram de ser funcionais à vida social dos cidadãos. Finalmente, os surveys permitiram a comprovação da hipótese de que os policiais que manifestam mais intensamente sua expectativa de reciprocidade têm mais chance de encontrar confiança nas interações com os cidadãos.

Palavras-chave: Confiança, Reciprocidade, Polícia, Função Policial, Etnometodologia. 